\title{
AN ANALYSIS OF STUDENTS' LANGUAGE LEARNING STRATEGIES IN ACADEMIC WRITING
}

\author{
Restu Winarsih $^{1}$, Urai Salam ${ }^{2}$, Dwi Riyanti ${ }^{3}$ \\ restu.winarsih@aiesec.net ${ }^{1}$ \\ urai.salam@untan.ac.id ${ }^{2}$ \\ dw_riyanti@yahoo.com ${ }^{3}$
}

Tanjungpura University

\begin{abstract}
This research was aimed to investigate students' writing strategies in enhancing their English academic writing skills. This case study interviewed two students from English Department to reveal students' strategies in academic writing. The data were collected using semi-structured interviews and document reviews. The findings showed that the two students who categorized as good language learners in writing skills employed all five writing strategies as proposed by $\mathrm{Mu}$ (2005) in their writing process. The data showed that metacognitive strategies and social/affective strategies were used most by the students. The strategies were organizing strategies, resourcing, setting goals, reviewing and editing, and avoidance strategies. The data also indicated that the two students were not achieving the goal of learning instantly. They employed strategies effectively in their individual learning in enhancing their writing skills.
\end{abstract}

\section{Keywords: Writing Skills, Writing Strategies, Academic Writing}

\section{INTRODUCTION}

Writing, to many students, is a challenging subject to master and even more difficult in foreign language situations. Within educational contexts, the capability to write well academically plays a pivotal role, especially for collegelevel students. However, since English is not a first language (L1) for Indonesian students, English academic writing became more demanding for students to learn as they experienced two challenges at the same time, i.e., learning the target language as well as mastering academic writing skills.

The English students in many universities in Indonesia were expected to have already had a proficiency in English writing skills in their six semesters of study. However, it was found in this current study that many students claimed 
that they still did not get used to writing in English, especially for academic contexts. Even though the students had had about five writing courses in their three years of study, they claimed that it was still hard for them to produce an academic text. The aspects concerned in an academic text includes the complexity, formality, objectivity, explicitness, hedging, and responsibility. Such comprehensive aspects heightened their anxiety levels. Erkan and Saban (2011) argue that the students' anxiety in the learning process often leads to the discouragement and might cause learners' negative attitude toward writing. Therefore, certain strategies played an essential role in helping students to overcome their anxieties and difficulties in writing.

The existing body of research in the area of second language learning strategies had mainly been focused on successful learners (Salam, Sukarti, \& Arifin, 2020). The use of LLS was highly influential in distinguishing more proficient language learners and less proficient learners. Current research on successful learners in language learning had also focused on documenting the link between second language (L2) writing proficiency and writing strategies. Writing strategies were recognized to be fundamental in helping successful writers enhance their writing skills. It was used to take control of learners' individual learning as well as improve learners' writing skills in a better way.

The effect of writing strategies on EFL (English as the foreign language) or ESL (English as the second language) learners' writing proficiency had been the focus of the researchers. Many recent studies (Maftoon \& Seyyedrezaei, 2012; Chand, 2014; Raoofi et al., 2014; Raoofi et al., 2017; Mastan et al., 2017) had investigated the role of writing strategies with writing performance. For instance, a study conducted by Mastan et al. (2017) on 36 intermediate ESL students revealed that the use of effective writing strategies had been shown to assist ESL/EFL learners in their writing skills. The study had also shown that the explicit instruction of writing strategies had a positive effect on ESL students' writing performance.

Other studies had been carried out on how language learning strategies were related related to students' language performance (Rarastuti, 2014; Kartikasari, 2015; Margareta, 2016; Sudharni, 2017). Nevertheless, there were only few studies exploring the specific learning strategies employed by undergraduate students in learning L2 academic writing. Therefore, this present study set out to investigate the learning strategies specifically in academic writing employed by students majoring in English.

\section{THEORETICAL FRAMEWORKS}

The term language learning strategies (LLS) was first introduced by Rubin and Stern in 1975. In recent years, varying definitions of LLS have emerged and defined in many ways. In 1990, O'Malley and Chamot popularized the term LLS to describe "the special thoughts or behaviors that individuals use to help them 
comprehend, learn, or retain new information." (p.1). This definition includes particular choices picked by language learners to help them in comprehending new information. Oxford (1990), Dornyei (2005), and Cohen (2011) also attribute the learning processes to strategies employed by learners in the acquisition of knowledge. Meanwhile, Brown (2000) described LLS as a "problem solver". It means specific actions or techniques used by language learners to help them solve the problems in the language learning process. Brown argues that these specific actions are employed by proficient language learners based on its appropriateness with task specifications. Since the definition of LLS varied among researchers, it was important to clarify how the definition agrees in one aspect: that LLS are planned, conscious and well-thought-out actions taken by learners purposively to facilitate individual learning effectiveness. These activities were employed to make individual learning became enjoyable and more effective.

Language learning strategies in this study were interpreted as activities that consciously carried out by students in order to improve their writing skills. However, not all activities or actions that were done by the students could be categorized as strategies. A number of basic characteristics had been formulated as references to identify whether an action was a strategy or just an ordinary learning activity. Therefore, in order to have a better understanding of language learning strategies, this section provides a brief description of the basic characteristics of language learning strategies by some experts.

Weinstein and Meyer (1991) offered three critical characteristics in identifying strategic learning activities. First, it must be goal-directed. It meant that the learning strategies were used to help the learners met a standard of performance or to reach the learning goal. Second, an action was considered as a strategic learning activity when it was intentionally invoked. The strategic activities were not universally applicable but more situation-specific. It implied some level of active selection by considering a number of factors, such as learners' prior experience with a strategy, prior experience with similar learning tasks, ability to deal with distractions, and commitment to goals. Then, the third characteristic was effortful. Strategic learning behaviours required time and often involved using multiple interactive steps. Because of the effort required, the learners must be motivated to initiate and maintain the strategy used.

Weinstein and Meyer's classifications of LLS focused on students' efforts to accomplish language tasks by employing certain strategies effectively in their individual learning. Riding and Rayner (1998) distinguished normal learning activities and strategic learning activities by considering its appropriateness. They argued that an activity became strategic when it was particularly appropriate for the individual learner, in contrast to general learning activities which a student might find it less helpful. It was believed that the learners engaged in strategic learning when they exerted purposeful effort to select and pursue learning 
procedures. The learners believed that these purposeful acts would increase their individual learning effectiveness.

On the other hand, $\mathrm{Mu}$ (2005) proposed three characteristics of language learning strategies. An activity was useful for the learners and considered as a strategy when it was under three characteristics. First, the strategy related well to the L2 task at hand. Second, the strategy fit the particular student's learning style preferences to one degree or another. Third, the student employed the strategy effectively and linked it with other relevant strategies.

Another characteristic had also proposed by Cohen (2011). He believed that the strategic learning activities should be voluntarily employed by the learners. According to Cohen, the element of choice was an essential feature to distinguish between ordinary learning activities and strategic learning activities because it gave a special character to a strategy. The notion of consciousness was believed to be essential in distinguishing strategies from those processes that were not strategic.

As described above, different experts had proposed their own characteristics of LLS in identifying learners' strategic learning behaviors. However, most of the characteristics proposed by the experts as mentioned above came up with quite similar points. The characteristics which were first proposed by Weinstein and Meyer had covered other experts' characteristics of LLS. Therefore, this study used the characteristics suggested by Weinsten and Meyer (1991) as references in distinguishing ordinary activities and strategic learning activities. This study considered one activity as a learning strategy when it was intentionally invoked by the learners to reach the learning goals and used effectively in their individual learning.

This research focused on describing students' strategies in learning academic writing by referring to Mu's (2005) taxonomy of ESL writing strategies. This taxonomy involved rhetorical strategies, cognitive strategies, metacognitive strategies, communicative strategies, and social/affective strategies. This study used Mu's taxonomy as guidance in conducting the present study because of its explicitness and accessibility. Besides, it was well-detailed classifications and the representative strategies in each strategy were provided in simpler actions.

\section{METHOD}

This study used a qualitative case study approach to investigate the students' language learning strategies in English academic writing. This design is to explore what or how rather than why something has happened (Cohen, Manion, \& Marrison, 2018). According to Yin (2014), qualitative case study research emphasizes to explore the essence of the phenomenon. This research design allowed the researchers to collaborate with participants by enabling them to share 
their views of reality, so the researchers got a better understanding of the participant's actions (Baxter \& Jack, 2010).

The purpose of this study was to find out what strategies used by students that made them proficient in English writing skills. Finding the unusual phenomenon in a particular group made this study had a unique problem that put it into a case study. The researchers used a case study research design because it allowed them to answer the "what" and "how" type of questions in exploring individuals. Regarding the focus of research, the researchers focused on describing students' writing strategies specifically in English academic writing skills.

\section{Subject of Research}

The participants of this study were those who have some qualities in writing competence. As this study was a Case Study, finding the participants meant finding the cases occurred in students that became the focus of this study. The study searched for students who had the following criteria: 1) having completed all the writing courses in their six semesters of study to secure that they had sufficient learning experiences in learning writing; 2) having excellent achievement in writing courses; 3 ) being recognized by their lecturers in writing classes for having good and positive attitudes toward writing; And 4) participating and active in writing activities in and outside the classroom.

By these criteria, the study could only have two participants. The decision to have these two students was based on the assumption that they processed knowledge and experienced with the phenomenon of interest in this studystudents' writing strategies in English academic writing. They were believed to have certain strategies to come up with the outstanding writing performance. It was assumed that they must have employed some strategies to enhance their English writing skills. Therefore, this study investigated these two students to answer the objectives of this research regarding writing strategies.

\section{Data Collection}

The data were derived from multiple sources through multiple methods - in particular, interviews (semi-structured interview), document reviews, and member checking (personal communication). The primary data collection method used in this study was an in-depth, semi-structured interviews with pre-prepared questions as a guidance for investigation. The interview was used to get the depth information about participants' writing experiences. The semi-structured interview was used in this research design because of its flexibility in which the questions could be developed at the time the interview took place.

After conducting the interviews, the researchers continue reviewing documents. The documents were useful in providing follow-up activities that were not observed. Therefore, the reviewed documents supplemented the interview data and thus served a useful information. The documents could be 
participants' notes on the list of vocabularies and phrases that they noted, the scores on all the writing courses in their six semesters of study (shown by the transcript), and their drafts in English writing.

After reviewing the documents, the researcher then conducted member checking. In this process, the participants were requested to examine rough drafts of writing where their actions or words were featured (Bowen, 2005). The participants were asked to review the material for accuracy and palatability. In this study, member checking involved the activity of telephoning respondents to check the accuracy of facts and observations. Cross-checking helped the researchers maintain reflexivity by encouraging self-awareness and selfcorrection.

\section{Data Analysis}

In relation to qualitative research methods, manual coding was used to analyze the transcribed interview data. The data for writing strategy used was coded using a typology based on Mu's (2005) taxonomy of L2 writing strategies, which was synthesized from previous L2 writing strategy research. According to Milles and Huberman (1984), there were three main components for analyzing data in qualitative research. They were data reduction, data display, and conclusion drawing or verification.

In this study, the researchers repeatedly read the transcripts to examine the data. The researchers reduced, summarized, and coded the interview data. The researchers displayed the data in this study in the form of a narrative explanation. It was linked and assembled systematically to answer the research questions.

The last stage was drawing conclusion and verification. An early conclusion was temporary and changed when stronger evidences were found. The conclusion was credible when the early conclusion was supported by valid and consistent evidence. In order to provide stronger evidences, the researcher did some reviews on participants' documents such as their notes and drafts during writing, then did crossed-checking to the individuals regarding the accuracy and palatability of the findings.

\section{FINDINGS AND DISCUSSION}

The data showed that metacognitive strategies and social/affective strategies were used most by the students. Based on the findings, there were six main activities which were represented metacognitive and social/affective strategies in the learning process experienced by the students. They were organizing strategies, resourcing, setting goals, reviewing and editing, and avoidance strategies.

The results showed that the students learned how to become better in writing skills by implementing certain actions to manage their motivation and behavior. The participants established a goal and action plan before they began the writing process. The results of the data analysis revealed that all participants employed a 
wide range of writing strategies, which could be categorized into rhetorical strategies, cognitive strategies, metacognitive strategies, communicative strategies, and social/affective strategies. However, each student had a preference for writing strategies and used them differently.

According to Dembo (2004), one of the major differences between successful and less successful individuals in any field was that successful individuals knew how to motivate themselves even when they did not feel enjoy performing a task, whereas less successful individuals had difficulty controlling their motivation. These attitudes were reported to be owned by the two participants. It was revealed that motivation was very fundamental for the participants in improving their ability in writing. The two participants were reported to have a long-term plan, which was to get a scholarship and continue their studies abroad. They knew the importance of having good ability in academic writing. Their dreams of going abroad motivated them to keep improving themselves, so they would be confident enough to accomplish the dream. As a result, they were more likely to complete a task at a higher level of proficiency.

The students in this study had similar concepts and aims in creating a concept map to organize ideas. The pre-writing activities assisted the learners to develop a tentative framework for writing. The results of the study indicated that the main activity done by the two participants in the pre-writing stage was planning, not only the content but also the organization of their papers. This finding was consistent with the view shared by $\mathrm{Mu}$ (2007) who argued that the good writers concerned themselves with ideas first. They made good use of the strategy of drafting an outline to guide their English writing. The participants in this study used a grouping strategy in activating background knowledge. They made a concept map depending on the text that would write.

Regarding grammar and content, either participant one or two agreed that fixing grammatical errors directly advantage writing skills. They argued that dealing with grammars and vocabulary provide great opportunities for them to improve writing skills. However, they also realized that in writing activities the content valued more important than grammar although with broken grammar ideas would not be easily undestandable. As it was reported in the semi-structured interview, both of the participants paid more attention to grammar because they found that they still needed some corrections in grammar for English was not their first language, but their main concern would be the flow of ideas in their writing - the content. This attitude was consistent with the studies conducted by Raimes (1985) and Bereiter and Scardamalia (1987) which suggested that more proficient English writers paid more attention to the content in writing rather than mechanical things. However, for both students were not English novice writers, they would still need to concern the grammar and vocabularies used in their writings. 
Another interesting point revealed in this study was that the two participants preferred the strategy of extensive reading in developing the ideas in their writings. The students faced difficulties in organizing the ideas for they were not familiar with the target field in English even though they have had some studies in the same field in Indonesian writing. They had to search for more information to familiarize themselves with the target field and generate more ideas to satisfy the target academic community. Therefore, they enriched themselves with knowledge of L2 writing by finding good writing models as references. The students read the outlines or thought about the questions before they began to write. While reading extensively the model writings, the students learned idiomatic expressions from extensive reading in their research field. They facilitated reading comprehension and memory. This finding was consistent with Hinkle's finding (2004) that second-language writers highly depend on resources for more information and language borrowings. They accumulated considerable content and then removed unnecessary material. This strategy could help novice writers wrote a long essay without too much retrieval from long-term memory. During reading, L2 writers paraphrased the appropriate sentences and used them in their drafts or papers.

A study conducted by Bransford and Johnson (as cited in Dembo, 2004) in understanding the importance of prior knowledge in writing revealed that the writers would have a better understanding of the incoming information when they had had the prior knowledge of the topic being discussed, even if it was only a little information. This study supported the finding in this study that the outlines or concept map helped the students to generate ideas. The students made a note about what they had already known about the topic. Then, they began to collect information and corrected whether the information on the outlines or concept map was appropriate or not. The students explained that note-taking was easier when they knew something about the material being presented. The effect was the same when they read the assigned material before taking lecture notes. This action was supported by Halpern (1996) who argued that the students took advantage of significant to facilitate comprehension and memory when they read outlines or thought about questions before they began reading the material references.

In order to enrich their knowledge on the topic being written, the two participants employed resourcing activities. Resourcing played an important role in writing skills. Both students in this study agreed that a good model of writing as the referenced material was one of the most useful resources for them at the pre-writing stage. As Swales and Feak (2000) have pointed out, learning to look for and analyze good writing models was a skill that would be highly helpful to second-language writers. Both students in this study preferred to use the sources that were spoken and written in English because they believed that credible sources could give them useful information. However, there was a difference in the choice of sources between participants. 
The participants were reported to implement the technology in their individual learning practice. As for participant one, he explained to be likely watching some videos on YouTube in enriching his knowledge of the topic being written. In his opinion, discovering information through YouTube was the simplest and pleasing way to do, as he could find and watch the video everywhere and every time he needed. This behavior was consistent with the view shared by Larsen-Freeman and Anderson (2011) that technology offered teaching resources and provided the learners' world to learning experiences. By implementing technology, the learners could be supplied with many genuine materials and they could be more motivated in language learning. The implementation of technology enabled the learners to learn on the grounds of their interests. It also satisfied the learners' visual and auditory senses. (Solanki \& Shyamleel; 2012, Gilakjani; 2017).

The findings in this study backed up the claim strongly endorsed by Victori (1999) who revealed that successful student writers showed both clearer knowledge and greater awareness concerning the strategies they used and the problems they faced in their writing. In the revising stage, the students were mainly focused on the problems associated with writing coherence and lexical errors such as grammatical mistakes, textual coherence, writing cohesion, and word choices. In order to deal with these writing challenges, the two participants set up some activities. For example, participant two was aware that English writing especially in an academic context was giving more challenges than writing in their native language, even just for selecting the words to be used. Therefore, in order to make his ideas sounded natural for the native readers, he used some applications in his gadget to help him with choosing appropriate words to be used in his academic writing. He also overcame the challenges in writing cohesion and coherence by asking for help from the lecturer and peers to evaluate his drafts before it came to the final one.

In sum, the language learning strategies used by the participants in this study were not too distinct between the participants. However, even though they had the same strategies, some activities that they chose were different based on their learning styles and preferences. The participants agreed if working on lexical errors and writing content helped them to improve the writing fluency. Being exposed to target language where they could practice language skills including reading, writing as well as sharing with others to seek help and discussion, were also shown as productive strategies for language skills like writing. The findings were in line with another study. For example, Okamura (2006) found that the students improve their language skill through reading resources written in English and communicating with English native speakers to look for some help. In addition, the students claimed they have other techniques that they apply frequently like reading general knowledge, taking short courses on writing, doing some exercises to improve vocabularies and grammars. 


\section{CONCLUSION AND SUGGESTION \\ Conclusion}

Regarding the research findings as explained in the previous chapter, it was found that the students who were categorized as good language learners in English writing skills used certain strategies to improve their English writing skills. This study demonstrated that the participants were not achieving the goal of learning instantly. They used different writing strategies and became a success in L2 writing depending on the use of appropriate writing strategies.

The students were reported using different types of metacognitive strategies such as planning and revising in their L2 writing, though other categories of writing strategies such as social/affective and cognitive strategies emerged from their interviews. However, the frequency of writing strategies used was categorized into dominant to less-used strategies.

Metacognitive strategies were the most dominant strategies used by the students in ESL writing, followed by social/affective strategies. Students were most likely to use metacognitive strategies that were practically planned, monitored, and evaluated for their writing. The participants also emphasized the importance of motivations and social interactions in the writing process. They were reported to seek help from the lecturers and their colleagues, especially from those who were well-skilled at writing. On the whole, the study revealed that the proficient writers were more successful in expressing and organizing their ideas. They overcame the challenges in writing by implementing concrete actions to deal with it.

In sum, different learners used different language learning strategies to improve their language skills and proficiency levels. From the study, the two participants preferred to employ metacognitive strategies and social/affective strategies compared to other strategies. Although language learning strategies varied from an individual to another, the findings in this research could give the students opportunities to choose and apply language learning strategies that suit them the best.

\section{Suggestion}

Despite the suggestive findings, there were several limitations in this study that need to be considered when interpreting the findings. First, the sample size was relatively small and limited to the sixth-semester students in one university, thus affecting the generalizability of the results. Second, this study used interviews, document reviews, and member checking for collecting data. It was suggested for the future researcher to do also re-checking with the lecturer who taught writing courses. It was essential to use a combination of qualitative and quantitative data 
collection instruments to get a better understanding of L2 writing strategies used by university students.

For both the students and the lecturer, it was suggested to address the techniques which helped learners to increase their knowledge in using of rhetorical conventions, coherence and cohesion devices and syntactic diversity in L2 writing. The students needed to find effective ways to help them developed their writing skills. Besides, the lecturer also needed to figure out different ways to encourage students to write in English, read and revise their texts, and give them feedback accordingly.

\section{REFERENCES}

Baxter, P. E., \& Jack, S. M. (2010). Qualitative case study methodology: Study design and implementation for Novice researchers. The Qualitative Report, 13(4), 544-559. Retrieved From http://www.nova.edu/ssss/QR/QR134/baxter.pdf

Bereiter, C., \& Scardamalia, M. (1987). The psychology of written composition. Hillsdale, NJ: L. Erlbaum.

Bowen, G. A.. (2005). Preparing a qualitative research-based dissertation: Lessons learned. The Qualitative Report, 10 (215), 208-222. Retrieved From http://www.nova.edu/ssss/QR/QR10-2/bowen.pdf

Brown, H. D. (2000). Principles of language learning and teaching (4th ed.). New York: Addison Wesley Longman.

Chand, Z. A. (2014). Language learning strategy use and its impact on proficiency in academic writing of tertiary students. Procedia-Social and Behavioral Sciences, 118 (2014), 511-521. DOI: 10.1016/j.sbspro.2014.02.070

Cohen, A. D. (2011). Strategies in Learning and Using a Second Language (2nd ed). London: Routledge Falmer.

Cohen, L., Manion, L., \& Marrison, K. (2018). Research Methods in Education (8th Ed). New York: Routledge

Dembo, M. H. (2004). Motivation and learning strategies for college success. Mahwah, NJ: Larence Erlbaum Associates.

Dornyei, Z. (2005). The psychology of the language learner: Individual differences in second language acquisition. Mahwah, NJ: Lawrence Erlbaum.

Erkan, D. Y., \& Saban, A. I. (2011). Writing performance relative to writing apprehension, self-efficacy in writing, and attitudes towards writing: A correlation study in Turkish tertiary-level EFL. Asian EFL Journal. Retrieved from www.asian-efl-journal.com 
Gilakjani, P. A. \& Sabouri, N. B. (2017). Advantages of using computer in teaching English pronunciation. International Journal of Research in English Education (IJREE), 2(3), 78-85. DOI:10.18869/acadpub.ijree.2.3.78

Halpren, D. F. (1996). Thought and knowledge: Introduction to critical thinking $\left(3^{\text {rd }}\right.$.ed.). Mahwah, NJ: Lawrence Erlbaum Associates.

Hinkle, E. (2004). Teaching academic ESL writing: Practical techniques in vocabulary and grammar. Mahwah, NJ: L. Erlbaum Associates.

Kartikasari, D. (2015). Language learning strategies in learning English (Unpublished Skripsi). Tanjungpura University.

Larsen-Freeman, D., \& Anderson, M. (2011). Techniques and principles in language teaching. Oxford: OUP.

Maftoon, P., \& Seyyedrezaei, S. H. (2012). Good language learner: A case study of writing strategies. Theory and Practice in Language Studies, 2(8), 15971602. DOI: $10.4304 /$ tpls.2.8.1597-1602.

Margareta, Y. (2016). An analysis on English learning strategies (Unpublished Skripsi). Tanjungpura University.

Mastan, M. E. B., Maarof, N., \& Embi, M. A. (2017). The effect of writing strategy instruction on ESL intermediate proficiency learners' writing performance. Journal of Educational Research and Review, 5(5), 71-78.

Miles, M. B., \& Huberman, A. M. (1984). Qualitative data analysis: An expanded sourcebook 2nd Ed. United States of America, USA: Sage Publications.

$\mathrm{Mu}$, C. (2005). A taxonomy of ESL writing strategies. In Proceedings Redesigning Pedagogy: Research, Policy, Practice, 1-10. Retrieved from https://eprints.qut.edu.au/secure/00000064/01/congjun-mu_paper.doc

$\mathrm{Mu}, \mathrm{C}$., \& Carrington, S. (2007). An investigation of three Chinese students' English writing strategies. TESL-EJ Teaching English as a Second or Foreign Language. Retrieved from www.asian-efl-journal.com

O'Malley, J., M. \& Chamot, A., U. (1990). Learning strategies in second language acquisition. Cambridge: Cambridge University Press.

Okamura, A. (2006). Two types of strategies used by Japanese scientists, when writing research articles in English. System, 34(1), 68-79. DOI: 10.1016/j.system.2005.03.006

Oxford, R.Y. (1990). Language learning strategies; What every teachers should know. New York: Newbury House Publishers.

Raimes, A. (1985). What unskilled ESL students do as they write: A classroom study of composing. TESOL Quarterly, 19 (2), 229-258.

Raoofi, S., Binandech, M., \& Rahmani, S. (2017). An investigation into writing strategies and writing proficiency of university students. Journal of Language Teaching and Research, 8(1), 191-198. DOI: $10.17507 /$ jtlr.0801.24 
Raoofi, S., Chan, S. H., Makundan, J., \& Rashid, S. M. (2014). A qualitative study into L2 writing strategies of university students. English Language teaching, 7(11), 39-45.s DOI:10.5539/elt.v7n11p39.

Rarastuti, T. P. (2014). A study on the students' language learning strategies in English foreign language reading (Unpublished Skripsi). Tanjungpura University.

Riding, R. \&Rayner, S. (1998). Cognitive styles and learning strategies. London: David Fulton Publishers.

Salam, U., Sukarti, \& Arifin, Z. (2020). An Analysis of Learning Styles and Learning Strategies Used by a Successful Language Learner. JET (Journal of English Teaching), 6(2), 111-121. DOI:10.33541/jet.v6i2.1734

Solanki, D., \& Shyamleel, M. P. (2012). Use of technology in English language teaching and learning: An analysis. 2012 International Conference on Language, Medias and Culture IPEDR vol. 33(2012). IACSIT Press, Singapore. 150-156.

Sudharni. (2017). An analysis of student's language learning strategies in speaking: A case study to the third semester student of English education study program (Unpublished Skripsi). Tanjungpura University.

Swales, J. M., \& Feak, C. B. (2000). English in today's research world. Ann Arbor, MI: The University of Michigan Press.

Victori, M. (1999). An analysis of writing knowledge in EFL composing: A case study of two effective and two less effective writers. System, 27(4), 537555. DOI: 10.1016/S0346-251X(99)00049-4

Weinstein, C. E., \& Meyer, D. K. (1991). Cognitive learning strategies and college teaching. New directions for Teaching and Learning, 45, 15-26.

Yin, R. K. (2014). Case Study Research Design and Methods. London: SAGE Publication 